\title{
Note on Transliteration, Abbreviations, and Names
}

Most of the Sanskrit and Hindi words in this text were transliterated according to conventions set forth by the U.S. Library of Congress. These words are italicized, except for proper names, with adjacent translations at their first usage and glossary entries for repeated words. Diacritical marks were removed from proper names of deities, people, and places.

Whenever possible, words are spelled according to their most common usage. Therefore, many of the - $a$ endings in Sanskrit were dropped in favor of their standard Hindi forms, except for common terms such as karma. In addition, diacritical marks and italicization were left out of common terms such as ashram. For the sake of consistency within English sentences, I end plural Sanskrit and Hindi words with an $s$ instead of a nasalized vowel. All $s$ and ś consonants were transliterated into $s h$.

Abbreviations of sacred texts:

CS Caraka Saṃhitā

KKh Kāshī Kanda

RV Reg Veda Saṃhitā

SP Skanda Purāna

For the sake of informant confidentiality, I altered the names and identifying information of patients, ashram residents, and other interview participants. Although the Mishra family did not object to having their real names in this book-which they have previewed and approved-I nevertheless altered their names as a matter of convention. I use the real names of public figures such as the Aghori babas and the medical officers of ashram clinics. 
